Revue Revue de l'histoire des religions

de Ihistoire des religions

2| 2016

La représentation juive de l'empire romain comme pendant et frère jumeau d'Israël. Histoire et enjeux

\title{
The Use of Rabbinic Traditions about Rome in the
} Babylonian Talmud

L'usage des traditions rabbiniques à propos de Rome dans le Talmud de Babylone

\section{Ron Naiweld}

\section{OpenEdition}

\section{Journals}

Electronic version

URL: http://journals.openedition.org/rhr/8557

DOI: 10.4000/rhr.8557

ISSN: 2105-2573

\section{Publisher}

Armand Colin

\section{Printed version}

Date of publication: 1 June 2016

Number of pages: $255-285$

ISBN: 978-2-200-93060-8

ISSN: 0035-1423

Electronic reference

Ron Naiweld, «The Use of Rabbinic Traditions about Rome in the Babylonian Talmud », Revue de I'histoire des religions [Online], 2 | 2016, Online since 01 June 2019, connection on 05 September 2020. URL : http://journals.openedition.org/rhr/8557 ; DOI : https://doi.org/10.4000/rhr.8557 


\section{The Use of Rabbinic Traditions about Rome in the Babylonian Talmud}

The article claims that the Talmud of Babylonia uses ancient traditions about Rome in order to create a fantasized world-system in which Rome and Israel function as two complementary and eternal rivals. The analysis of several Talmudic sources shows that the Babylonian rabbis inherited the complicated image of Rome together with the rest of the rabbinic traditions that arrived in Babylonia from Palestine during the $3^{\text {rd }}$ and $4^{\text {th }}$ century CE. It further shows that the Babylonian rabbis reworked the Palestinian rabbinic image of Rome and transformed it into the structural parallel of Israel. Thus, they sustained the symbolic power of the Roman empire, even though they lived outside of it. Rome became for them a mirror image of Israel, which, in turn, became a "spiritual" Empire, protected by the highest King - God.

\section{L'usage des traditions rabbiniques à propos de Rome dans le Talmud de Babylone}

Cet article avance l'idée que le Talmud de Babylone utilise des traditions anciennes sur Rome afin d'établir un "système-monde" dans lequel Rome et Israël entretiennent une relation conflictuelle, complémentaire et éternelle. L'analyse des sources talmudiques montre que les rabbins babyloniens héritèrent l'image complexe de Rome avec le reste des traditions rabbiniques au cours du III et du IV siècle de notre ère puis qu'ils retravaillèrent l'image palestinienne de Rome afin d'établir un parallélisme entre ce dernier et Israël. Ils soutinrent ainsi le pouvoir symbolique de l'empire romain, tout en vivant en dehors de celui-ci. Rome devint pour eux une image miroir d'Israël, qui, à son tour, devint un empire "spirituel », protégé par le roi des rois - Dieu. 


\section{Introduction. The Symbolic Existence of Rome AND THE Babylonian TALMUd}

There are many ways in which an Empire exists - as a political entity organizing various aspects of the life of its habitants; as an economic power, producing and distributing riches and controlling the division of labor; as a global actor, negotiating with foreign political entities, trying to conserve its interests while constantly redefining them. All of these "imperial forms of existence" are more or less easy to discern; they are traceable, since they produce objective evidence. This, however, is hardly true in the case of the form of existence that will be dealt with in this article. For, besides being or having an economic, political, and military power, an empire also constitutes a symbolic one; in other words, it exists in the minds of the people, whether they live inside it, or in countries and regions where its influence can be felt. The symbolic power of an empire is certainly supported by its economy and military force but, at the same time, it contributes to their success; it determines the range and the depth of its influence and plays a crucial role in the relationship that the empire entertains with its internal and external others, whether they are individuals, cities, provinces, or neighboring empires.

By using the term "symbolic power" I am indebted mainly to the French sociologist Pierre Bourdieu, who articulated this idea in the context of modern state and society. ${ }^{1}$ For the purpose of this paper, we can define it as the capacity of the group holding this power to impose its will on others without using physical force. The subjects who obey the will of the symbolically powerful empire will do so because they have internalized the values and the worldview of the empire, and therefore believe in the necessity of their domination.

This article is based on a paper presented at the conference "Judaism and the Political and Religious Challenge of the Roman Empire" (Aix en Provence, July 2012). I would like to thank the organizer of the conference, Katell Berthelot, and the other participants for their insightful remarks.

1. Pierre Bourdieu, Language and Symbolic Power, ed. John B. Thompson, transl. Gino Raymond and Matthew Adamson, Cambridge, Harvard University Press, 1991, p. 163-170. 
The symbolic power of an empire is much more difficult to grasp than its more visible powers, since it has a very strong subjective dimension that may change from one person to the other, even when both of them entertain the same "objective" relationship with the empire in question. In this paper I will not attempt, of course, to offer an account of the symbolic power of the Roman Empire. ${ }^{2}$ What I will try to do instead is to show how this symbolic power was perceived outside the Roman Empire, by a group of people whose religious, ideological, and cultural relationships with the empire were multilayered and extremely complex. The group in question consisted of some Babylonian Jews who were active in Babylonia between the third and the seventh centuries, and who integrated stories and anecdotes about Rome into their teachings. These, in turn, were compiled in various places in the Talmud of Babylonia that was redacted between the sixth and eighth centuries in the Sasanian Empire.

But before entering the crux of the discussion, I must answer the following question - how can one speak of a symbolic power outside the realm of the actual, recognized political power of the entity in question: the Roman Empire? Indeed, when Bourdieu articulates the concept of "symbolic power" he refers to its appearance inside the political or social system in which it operates. A symbolic power cannot oppress someone who is outside its sphere of influence. This assumption is so obvious that Bourdieu does not even bother to state it. The political entity that exercises symbolic power does so by what Bourdieu calls "symbolic instruments": ideologies, symbolic objects and forms, and finally means of communication that will allow the articulation and the propagation of the imperial perception of the world. But in order to function, a symbolic power has to be recognized by those affected by it. Thus, according to Bourdieu, the "symbolic power does not reside in 'symbolic system' in the form of an 'illocutionary force' but [...] it is defined in and through a given relation between those who exercise power and those who submit to it". ${ }^{3}$

2. This, to a certain extent, is the project of Clifford Ando's 2000 book, in which theories of Habermas and Bourdieu are employed in order to explain the ways by which the empire installed consensus, legitimacy, and loyalty in its provinces: Clifford Ando, Imperial Ideology and Provincial Loyalty in the Roman Empire, Berkeley, University of California Press, 2000.

3. P. Bourdieu, Language, p. 170. 
Can we talk then about the Babylonian Jews who redacted the Babylonian Talmud as "those who submit" to the symbolic power of the Roman Empire? The basic assumption of the present article is that the answer to this question is positive, but that it requires us to rethink the relationship between the two categories that Bourdieu defines too rigidly - those who exercise the symbolic power and those who submit to it. The analysis proposed here will allow us not only to nuance the relationship between the two categories, but also to propose that, at least in the case examined here, an actual political power takes on a symbolic life of its own, which has the potential to be manipulated in unpredictable ways. As we will see, the image of Rome created in the second and third centuries by Palestinian rabbis had an enormous influence on the nascent rabbinic movement in Babylonia. The Babylonian rabbis used it in order to define not only themselves, but also the amorphous and politically and geographically dispersed entity that was Israel. The acceptance of the Babylonian Talmud as the defining religious corpus of the Jewish people guaranteed that even after the fall of Rome, its symbolic power would continue to design the experience of the Jews.

\section{Rome in Babylonia?}

The redactors of the Babylonian Talmud, as well as the rabbis who were active in Babylonia before them, considered themselves to be members of a religious, intellectual, and ideological movement that was born in Roman Palestine. They organized their curriculum according to the Mishnah - a text redacted in Palestine at the beginning of the third century. Their teachings were based in large part on texts and traditions that came from Palestine before and after the redaction of the Mishnah. As Richard Kalmin has shown, the Babylonian rabbis received Jewish Palestinian traditions that originated outside rabbinic circles, ${ }^{4}$ but their main source was

4. Richard Kalmin, Jewish Babylonia between Persia and Roman Palestine, Oxford: Oxford University Press, 2006. See also Yaakov Elman, "Rava and Palestinian Systems of Midrash Halakha," Center and Diaspora: The Land of Israel and the Diaspora in the Second Temple, Mishna and Talmud Period, ed. Isaiah M. Gafni, Jerusalem, Zalman Shazar, 2004, p. 217-242 (in Hebrew). 
rabbinic compilations and compositions produced in Palestine between the second and fourth centuries CE. In other words, the basis of rabbinic activity in Babylonia consisted of a group of texts that were redacted in a Roman environment and contained many explicit and implicit references to Roman practices, ideas, and values. These texts transmitted an image of Rome that the Babylonian rabbis used and reshaped in ways that will be examined in this article. But before that, we must first better understand one essential quality of the Palestinian rabbinic image of Rome.

The presumption of this article, every part of which can admittedly be debated, is that Palestinian rabbis used Roman ideas, values, and practices in order to define their own identity. By distinguishing themselves from the Roman other, they could conceive of their "rabbinic" selves. Seth Schwartz has argued that the Palestinian rabbinic opposition to Rome was profound and virulent, not so much on a political level as on a cultural and ideological one. ${ }^{5}$ The Palestinian rabbis thought of Rome as the wicked kingdom that in its very existence and by its cruel and mighty power denied the full realization of their project. In fact, the rabbis inherited the old conception of Rome as the great enemy of the Jews and fashioned it in order to promote their own version of Judaism. Thus, one of the messages coded in the Palestinian rabbinic traditions about Rome is that since Rome is the enemy of Judaism, and since the Judaism that provokes Rome's animosity is rabbinic Judaism, then the latter is the legitimate and normative form of Judaism. ${ }^{6}$

The ideological potential of this message is clear, and it is out of the scope of this article to ask what contribution it made to the long

On the general question of the relationship between the rabbinic centers in Babylonia and Palestine during the Talmudic period, see from the same volume: Aharon Oppenheimer, "Links between the Land of Israel and Babylonia during the Transition from the Tannaitic to the Amoraic Period," Center and Diaspora, p. $125-140$.

5. Seth Schwartz, "Rabbinic Culture' and Roman Culture," Rabbinic Texts and the History of Late-Roman Palestine, ed. Martin Goodman and Philippe Alexander, Oxford, Oxford University Press, 2010, p. 283-299. See also Hayim Lapin, Rabbis as Romans. The Rabbinic Movement in Palestine, 100-400 CE, Oxford, Oxford University Press, 2012.

6. Of course, one should not consider that the Palestinian relation to Rome was the same throughout late antiquity. As we shall see, it is probable that during the beginning of the third century the animosity towards Rome became less visceral. 
and complex process of the "rabbinization" of Palestinian Judaism. What is important for us to keep in mind is that the Palestinian rabbis thought of themselves as living in the land of the enemy, but on a very important symbolic level this land was still their own: Rome was the land of exile, but at the same time it was home. This double dimension of the empire, a place that is both home and exile, is what made the Palestinian image of Rome so complex, intense, and rich.

When the Palestinian rabbinic traditions arrived in Babylonia, in the third and fourth century CE, they brought with them this highly charged image of Rome. What they did not bring, however, was the context in which the rabbinic opposition to Rome was originally articulated and developed. To put it simply, for the Babylonian rabbis, Rome was not home. Thus, when they studied and reworked the Palestinian traditions, they were free to develop the idea of Rome as the land of exile, without being very troubled by the fact that the land of Israel was situated inside it. Their homeland was Babylonia, and the very fact that they engaged in rabbinic activity in the land of their fathers, showed that they considered that the full realization of the rabbinic identity could take place outside of Eretz Israel, in the paradigmatic place of the galut - Babylonia. ${ }^{7}$ Although they were aware of the fact that on some level they lived in exile, still, for them, Babylonia was home, ${ }^{8}$ and Rome came to represent where the exile was. ${ }^{9}$

7. This point touches the general problem concerning the relationship of Babylonian rabbis to the land of Israel. See Jeffrey Rubenstein, "Addressing the Attributes of the Land of Israel: An Analysis of Bavli Ketubot 110b-112a," Center and Diaspora, p. 159-188 (in Hebrew); Isaiah M. Gafni, Land, Center and Diaspora: Jewish Constructs in Late Antiquity, Sheffield, Sheffield Academic Press (Journal for the Study of the Pseudepigraphia, Supplement Series 21), 1997, p. 96-117.

8. The view of Babylonia as home is already found in the Tosefta, probably redacted in Palestine in the third century, in a statement attributed to Rabban Yohanan ben Zakai: "Why has the majority of Israel been exiled in Babylonia? Because the house of Abraham their father was from there. It is like a woman who has upset her husband; where does he send her? To the house of her father" (Tos. BQ 7:2). In $b$. Pesahim 87b, the same saying is attributed to the third-century Palestinian sage - R. Yohanan).

9. In fact, during the Geonic period, when the stakes of the conflict between the Palestinian and Babylonian rabbinic centers became more important than ever, the fact that Palestinian Judaism suffered from Roman persecutions was used in order to attack the validity of Palestinian Halakha. This is one of the arguments in the combative letter of the Babylonian Pirkoi ben Baboi in which he lays claim to 
Thus, the rabbinic image of Rome stood in Babylonia for something quite different than in Palestine; it became a conceptual lieu de mémoire, a new paradigmatic place of the galut, where Judaism was compromised and put in danger. ${ }^{10}$ Like their Palestinian counterparts, the Babylonian rabbis viewed Rome as the greatest enemy of Judaism, but it was an abstract enemy and not an actual one; for them Rome was mainly the image of a political and ideological power. In other words, it did not represent an actual power, with which they had to deal on a daily basis; its symbolic value was not intertwined with political, social, economic, and religious factors that had a real impact on their everyday life. Thanks to the fact that the actual Rome was elsewhere, ${ }^{11}$ the Babylonian image of it was free to become the unquestionable and eternal Other of rabbinic Judaism, ${ }^{12}$ a mirror image of "Israel".

the supremacy of the Babylonian Halakha. See Gafni, Land, Center and Diaspora, p. 96.

10. The following statement of Rabbi Hiya, a second-century Palestinian Sage of Babylonian origin, seems relevant in this context: "God knows that Israel cannot bear the decrees of the Romans, therefore He sent them to Babylonia" (b. Pesahim 87b; Gittin 17a).

11. As years went by, Palestinian Rome got more and more distant chronologically, but also geographically (fewer rabbis traveled from one rabbinic center to the other). We will see in the following that, indeed, the later the source, the more abstract its image of Rome.

12. For a brilliant analysis of some case studies of Babylonian manipulation of Palestinian sources, see Jeffrey Rubenstein, Talmudic Stories: Narrative Art, Composition and Culture, Baltimore, John Hopkins University Press, 1999; id., The Culture of the Babylonian Talmud, Baltimore, John Hopkins University Press, 2003. For a case more relevant to our discussion, in which the Babylonian redactors use the Palestinian tradition about Rome in order to articulate their political vision, see Charlotte Elisheva Fonrobert, "Plato and Rabbi Shimon Bar Yohahi's Cave (B. Shabbat 33B-34A): The Talmudic Inversion of Plato's Politics of Philosophy," AJS Review 31/2 (2007), p. 277-296. As for the specific question dealt with in this article, on the techniques and methods used by the redactors of the Bavli when they incorporated Palestinian traditions about Rome, see Paul Mandel, "Tales of the Destruction of the Temple': Between the Land of Israel and Babylonia," Center and Diaspora: The Land of Israel and the Diaspora in the Second Temple, Mishna and Talmud Period, ed. Isaiah M. Gafni, Jerusalem, Zalman Shazar, 2004, p. 141-158 (in Hebrew). Mandel's analysis of some destruction stories shows that in many cases the Babylonian rabbis used these traditions in order to shed light on problematic attitudes and behaviors in their own circles. 


\section{Status Quaestionis - The Representation of RoMe IN THE BAVLI}

No study has been dedicated so far to the question of the representation of Rome in the Babylonian Talmud. Two important books deal with the image of Rome and Persia in rabbinic literature in general: Samuel Krauss's Hebrew book from 1947, Persia and Rome in the Talmud and the Midrashim (Jerusalem, Bialik Institute), and Jacob Neusner's Persia and Rome in Classical Judaism, from 2008. Both books can be regarded as compilations of rabbinic sources with some analysis. Krauss divided his book into thematic sections in which he organized pericopes, stories, laws, and traditions from the entire range of classic rabbinic literature, with very little attention to the date or provenance of the teaching in question. Neusner, loyal to his "documentary" approach, divided the texts according to the supposed date of redaction of the compilation in which they occur. ${ }^{13}$ Contrary to Krauss, Neusner is aware of the historicity of the sources, and he articulates a historical development in which the main turning point is in the fourth century with the Christianization of the Roman Empire. It is as of this moment, according to him, that rabbinic redactors refer to Rome mainly as a Christian entity that is a theological rival and not a political one.

Neusner's picture is too schematic and simple. Just like Krauss, he does not distinguish between Palestinian and Babylonian texts. He relies solely on the chronological factor, without giving any attention to the geographical one. Thus, he includes Palestinian exegetical compilations in the same section as the Bavli since he assumes that all these texts were redacted during the same period (500 to $600 \mathrm{CE}$ ). However, the bare fact that the Talmud of Babylonia was redacted outside the Roman Empire makes the geographical factor extremely important.

The discussion proposed here is also connected to what can be qualified as a growing tension inside contemporary Talmudic studies. On one pole of this tension stands a group of scholars, Yaakov Elman being probably their most engaged defender, who emphasize the Zoroastrian context of the Talmud of Babylon, claiming that

13. According to Neusner's documentary approach, a rabbinic text can only reflect the historical reality of the time of its redaction. 
its redactors are heavily influenced by their Sasanian religious and political environment, and that in order to fully understand the environment of the Bavli, the Persian one must be taken into consideration. ${ }^{14}$ In many ways this position can be understood as a reaction to the more traditional view, held more or less implicitly by many past and present scholars according to whom the Babylonian Talmud is a rabbinic text, and by rabbinic they mean a product of a Jewish Palestinian ideological/religious movement. These scholars have assumed that when rabbinic discourse arrived in Babylonia, it preserved its intrinsic rabbinic and Palestinian traits and continued to develop according to its own logic without being heavily influenced, if at all, by its Persian environment. In recent years, and not without connection to the growing interest in the Zoroastrian context of the Babylonian Talmud, new scholarship has been trying to defend this traditional position. Thus, Daniel Boyarin considers the rabbinic class in Babylonia as Hellenistic, when he points out, for instance, the affinities between the Babylonian Talmud and platonic dialogues. Richard Kalmin speaks of a rabbinic class whose main influence was literary and not circumstantial. Thus, he claims that Palestinian rabbinic and non-rabbinic materials that arrived in Babylonia in the course of the fourth century influenced the development of rabbinic discourse much more than the actual historical context. ${ }^{15}$

The present article does not intend to take part in this polemic. It may, however, shed some light on it by examining the use of the Palestinian traditions by the Babylonian rabbis, and the ways in which a Palestinian image, that of Rome in our case, was imported and manipulated in the Babylonian context.

14. See the recent book: Shai Secunda, The Iranian Talmud: Reading the Bavli in its Sasanian Context, Philadelphia, University of Pennsylvania Press, 2013.

15. See R. Kalmin, Jewish Babylonia; Daniel Boyarin, Socrates and the Fat Rabbis, Chicago, Chicago University Press, 2009. 


\section{Eternal Rome and the Scholasticization of Rabbinic Discourse}

One of the best examples of the different attitude of Babylonian rabbinic discourse towards Rome with regard to Palestinian rabbinic sources is the eschatological aggadah from the beginning of the Avodah Zarah tractate. The aggadah, in Hebrew, is attributed to Palestinian sages either from the end of the third century (R. Hanina ben Papa) or the first half of the same century (R. Simlai ${ }^{16}$ ). However, the Hebrew narrative is interrupted many times with interrogations, explanations, and discussions - most of them in Aramaic. J. Rubenstein, who analyzed this text, ${ }^{17}$ sees here a classic case of an intervention of the later redactors of the text, the stamaim, who were active circa the eighth century. ${ }^{18}$

The Hebrew text begins by telling how in the "future to come," God "will bring the book of the Torah and set it in his lap and say: 'Everyone who busied himself with this may come and take his reward. ${ }^{19}$ " The story goes on to tell how several kingdoms presented themselves before God in response to his call. The first one is Rome, who enters "right away". The Aramaic gloss breaks that narrative here in order to ask why the Romans were the first to enter. The answer it provides is falsely simple - "because they are the most important".

In fact, what the Babylonian gloss does is to reverse the meaning of the original story. Read without the Aramaic interpolation, the story depicts Rome as a pretentious and insolent kingdom, who hurries to answer God's call. Indeed, the mere suggestion that the Romans can be considered as people who "busied themselves with the Torah" should make the readers or listeners of the original story laugh. But for the Babylonian redactors, this critique disappears; they give a very straightforward explanation to the fact that Rome entered first - it is the most important kingdom. Moreover, in the parable they use in order to prove that the most important one enters first, they compare Rome to a king. In short, the power of Rome is taken by them much more seriously, and without a hint of irony.

16. According to the New York manuscript $-\mathrm{R}$ Shila (a Palestinian rabbi contemporary to R. Simlai).

17. J. L. Rubenstein, Talmudic Stories, 215-242.

18. Ibid.

19. Translation based on the Paris manuscript. 
What this Babylonian passage shows us is how the rabbis in Babylonia ignored, consciously or not, the emotional impact that such declarations about the greatness of Rome could have had on their Palestinian colleagues. Rome, as I would like to claim, represents in Babylonian rabbinic literature a discursive object rather than a real one. This, of course, did not happen overnight, and when the Palestinian traditions about Rome first arrived in Babylonia it was still difficult to disconnect them from the historical background from which they had emerged.

Some passages from the Bavli attest to the process through which Palestinian-Roman traditions were discharged from their immediate emotional impact:

A. Rabbi Yehoshoua ben Levi in the name of Rabbi [Yehuda the patriarch] said: Rome will fall into the hands of Persia, as it is said: "Therefore hear the counsel of the Lord, that He has taken against Edom, and His purposes that He has purposed against the inhabitants of Teman. The young of the flock will be dragged away, their habitation will fall upon them" (Jer. 49:20).

B. Rabbah ben 'Ullah objected: What indicates that "the young of the flock' refers to Persia? [Presumably] the following verse: "The ram which you saw with two horns, they are the kings of Media and Persia" (Dan. 8:20). But this may refer to Greece, for it is written: "And the rough goat is the king of Greece" (Dan. 8:21).

When the master left, ${ }^{20} \mathrm{Habiba}$ b. Surmaki reported this [exchange] before a certain master. The latter said: One who cannot interpret Scripture objects Rabbi?

What, indeed, does "the young of the flock" mean? The youngest of his brethren, for R. Joseph learnt that Tiras is Persia. ${ }^{21}$

C. Rabbah ben Bar Hana said: R. Yohanan said in the name of R. Yehudah b. Ila'i: Rome will fall into the hands of Persia. That may be concluded a fortiori: The first Temple was built by the sons of Shem and destroyed by the Chaldeans [and then] the Chaldeans fell into the hands of the Persians. How much more should this be so with the second Temple, built by the Persians and destroyed by the Romans, that the Romans should fall into the hands of the Persians.

D. Rav said: Persia will fall into the hands of Rome. R. Kahana and R. Assi asked him: [Shall] the builders fall into the hands of the destroyers? He said to them: Yes, it is the decree of the King. Others say: He said to them: They also destroy synagogues.

20. This is how I translate כי סליק רב, assuming that the word "Rav" refers to Ben Ulla, and that the text depicts a scene in the study house. Some translators and commentators (e.g., the Soncino translation) take the word "Rav" as the title of Habiba.

21. Tiras is the youngest of Japheth's sons, according to the list in Genesis $10: 2$. 
E. It has also been taught: Persia will fall into the hands of Rome, first because they destroyed the synagogues, and then because it is the King's decree that the builders fall into the hands of the destroyers.

F. Rav also said: The son of David will not come until the wicked kingdom has spread over the whole world for nine months, as it is said: "Therefore He will give them up, until the time when she who is in labor has given birth; and the rest of his brothers shall return with the children of Israel" (Mic. 5:2). ${ }^{22}$

Most historical readings of this passage concerned themselves with the changing attitude of the rabbinic class towards Persia during the third century. ${ }^{23}$ These readings rely on the common assumption in Talmudic scholarship that one can detect a rupture in the rabbinic and Jewish attitudes towards Persia during the tormented transition period from the Perthian to Sasanian rule in the first half of the third century, and the persecutions of Kerdir towards the end of that century. They assume therefore that while parts $\mathbf{A}$ to $\mathbf{C}$ ("Rome will fall into the hands of Persia") reflect Jewish antagonism towards Rome in Palestine, parts D to E ("Persia will fall...") are the expression of the distress of Jews in Babylonia during the third century.$^{24}$ However, the picture seems to be more complicated than that. In fact, this passage is a compilation of several traditions, not organized according to their chronological order, which reflect the evolution of the rabbinic relation to Rome in both Palestine and Babylonia.

The passage suggests that a Palestinian rabbinic tradition, according to which Persia will conquer Rome, ${ }^{25}$ existed already in

22. b. Yoma 10a. For bibliography see R. Kalmin, Jewish Babylonia, p. 232, note 11 and notes hereafter.

23. See Isaiah Gafni, The Jews of Babylonia in the Talmudic Era: A social and Cultural History, Jerusalem, Zalman Shazar, 1990, p. 116 (in Hebrew). See also note 60 below.

24. Richard Kalmin, who argues against the assumption that the rabbis perceived the third century in Babylonia as a watershed in the Persian-Jewish relationship, reads the last parts as merely hermeneutic. In other words, according to Kalmin, Rav's statement is not a reaction to the reality of the Babylonian Jewry of his day, but rather the fruit of a purely scholastic activity. See Kalmin, Jewish Babylonia, pp. 122-129. The reading proposed here combines in fact both the historical approach of Isaiah Gafni and others, and the literary approach promoted by Kalmin, by referring to the historicity of the literary objects ("Rome," "Persia," "Scripture").

25. This, in fact, may be regarded as a Palestinian rabbinic topos that some scholars date back to the Temple period. See Isaiah Gafni, The Jews in Babylonia and their Institution in the Talmudic Period, Jerusalem, Zalman Shazar, 1975, p. 10 (in Hebrew). 
the middle of the second century - Yehudah ben Ilai's period of activity (part B).$^{26}$ The latter knew the horrors of the Bar Kokhba war, and his hope for the decline of Rome is thus more than understandable and does not need to be justified. Indeed, he did not bother to corroborate it with exegesis, since his interlocutors, in post-war Palestine, knew exactly what he was speaking of and probably identified with his message.

Rabbi Yehudah the Patrarich (part A), who was active at the beginning of the third century, could not or did not wish to ignore or repudiate the old tradition that predicted the annihilation of Rome by the Persians. But at the same time he could not fully adhere to it on a political level. The beginning of the third century is considered to be a "golden era" for the post-70 relations of Jews and Romans in Palestine, and the Patriarch himself was close to the Roman government. Therefore he transformed Yehudah ben Ilai's original saying into a rabbinic exegesis.

Part B shows that in the second half of the fourth century, a Babylonian rabbi, Rabbah ben Ulla, revised the teaching attributed to Rabbi. He proposed a better interpretation that questioned the validity of the rabbi's affirmation, and suggested that Greece, and not Persia, would conquer Rome. Rabbah ben Ulla's objection was clever, and it is even possible that Habiba, reporting it to "a certain master," did so out of enthusiasm - he wanted to share with him a good argument. The rabbi reacted, however, in a rather violent way and described ben Ulla as a pretentious scholar who knew nothing about interpreting Scripture.

Now, we cannot know what real political entities Rabbah ben Ulla had in mind when he spoke about Greece ${ }^{27}$ and Rome, but if I had to take a guess I would say none. It seems simply that when teaching or revising the rabbi's statement, he came up with a rather clever objection based on a possible scriptural interpretation. The harsh reaction of the master who hears his teaching may indeed be attributed to the fact that ben Ulla dared to question a midrash of the great Rabbi Yehuda, but I think that it is possible to detect here more than a simple criticism of ben Ulla's disrespect to his

26. See I. Ben Shalom, "Rabbi Judah B. Illai's Attitude towards Rome," Zion 49/1 (1984), p. 9-24 (in Hebrew), p. 17, note 40.

27. The term "Greece" is used sometimes to refer to the Parthian Empire in the Bavli. 
superior. What the rabbi condemns is ben Ulla's indifference with regard to the Palestinian aspiration to end Roman rule, an aspiration that must have been felt in the fourth century, by Palestinian rabbis but also by some of their Babylonian counterparts, who considered themselves to be members of the same movement, sharing the same destiny, hopes, and aspirations. ${ }^{28}$ When ben Ulla interprets Rabbi's teaching in a purely scholastic way, without paying attention to its emotional significance, he dissociates himself from his Palestinian colleagues; his scholastic approach to Rabbi's teaching shows that he ignores its true meaning - more than a simple midrash it is the expression of a political hope (the fall of Rome) that for some of his colleagues is still alive.

Parts D-F postulate an opposite view to the one expressed in parts $\mathrm{A}$ and $\mathrm{C}$. This view is attributed to Rav, one of the founders of the rabbinic movement in Babylonia, who was active during the first half of the third century - in other words, a period of transition between the Parthian and Sasanian empires that caused trouble and turmoil among Babylonian Jews. ${ }^{29}$ If the attribution of this statement to him is correct, we can thus perfectly understand its background, especially if we remember that Rav, who was a student of Rabbi in Galilee, knew the relatively good condition of Jews in Palestine at the beginning of the third century. ${ }^{30}$

Rav's statement is not supported by Scripture but by two arguments: ${ }^{31}$ 1. It is the decree of God ("the King") and 2. The

28. See for example A. Oppenheimer, "Links," p. 128, which speaks about certain hegemony of the Palestinian rabbinic movement over that of Babylonia towards the end of the third century.

29. The literature is abundant. See for example I. Gafni, The Jews of Babylonia, p. 39-43.

30. Several scholars have dealt specifically with the reference to Persia as destroying synagogues. Moshe Beer ("The Political Background of Rav's Activity in Babylonia," Zion 50 (1985), p. 155-172 (in Hebrew)) thinks that it reflects events that occurred during Rav's lifetime, while Eliezer S. Rosenthal ("For the Talmudic Dictionary - Talmudica Iranica," Irano-Judaica: Studies Relating to Jewish Contacts with Persian Culture Throughout the Ages, ed. Shaul Shaked, Jerusalem, Yad Ben Zvi, 1982, 38-134, p. 63-64 (in Hebrew)) connects it to the persecutions under Kerdir, dating it thus to the end of the third century. See also R. Kalmin, Jewish Babylonia, p. 127-128.

31. Part E shows that this tradition also existed anonymously; but it would be safe to claim that it was also formulated in the period of turmoil during the third century. Richard Kalmin (Jewish Babylonia, p. 232, note 6) draws attention to a passage of Aphrahat that "interprets the second beast in Daniel 7 as a reference to the kingdom of Media and Persia, and the fourth beast as a reference to the 
Persians destroy synagogues just like the Romans destroyed the Temple. ${ }^{32}$ The first argument is prophetic while the other expresses anger towards Persian rule for its awful deeds - these are compared to the destruction of the Temple! $!^{33}$ In other words, both arguments are the expression of the frustration of some Babylonian Jews visà-vis Persia, and their genuine preference to be under Roman rule, which they consider as a lesser evil.

The passage ends with an eschatological account (part F), which is impressively mild. No global war is mentioned, no mass destruction is predicted, only an expansion of the "wicked kingdom" in the entire world "for nine months". Now, it is always dangerous to connect two separate teachings in the Bavli, but in this case one must at least raise the possibility that the redactors of this passage allude to a tradition brought by a sugiya of tractate Megila:

What is meant by the verse "Do not grant, God, the desires of the wicked, do not draw out their bit, so that they exalt themselves, selah" (Ps 140:9)? Jacob said before the Holy One, blessed be He: Sovereign of the Universe, do not grant to Esau the wicked the desire of his heart, do not draw out his bit. This refers to Germamia of Edom, for without them, they [the Romans] would destroy the entire world... ${ }^{34}$

The picture portrayed by this description is that of a powerful empire that is always on the verge of becoming a world empire, but is blocked by another power that counterbalances it. It will be interesting to compare this tradition to what is probably its Palestinian pendant, from Genesis Rabbah. The Babylonian version, contrary to the Palestinian one, is followed by a teaching of Hama ben Hanina according to which "there are three hundred crowned heads in Germamia of Edom and three hundred and sixty-five chiefs in Rome, and every day one goes forth towards the other and one of them is killed, and they have trouble appointing a king". In other words, the war between the German tribes and the Romans cannot come to an end because on the one hand the Germans are almost

kingdom of the sons of Esau, i.e., to the Greek and Romans. Yet the ram, now symbolizing Shapur, fights the fourth beast, which is the Roman Empire. According to Aphrahat, the Roman Empire, which is Christian, will not be defeated until the coming of Christ".

32. Both Kalmin and Rosenthal consider that the second argument (they destroy synagogues) is a late interpolation.

33. See I. Gafni, Jewish Babylonia, p. 116.

34. b. Megillah 6a-b. 
as powerful as the Romans - only sixty-five warlords short; and on the other hand, they cannot appoint a king because they are too busy fighting Rome. Thus, if we read Rav's conclusion in part F in the light of the teaching from tractate Megila, we have to conclude that Rome will never be able to spread over the entire world.

In fact, one can read Rav's statement as saying: it does not really matter which kingdom will rule the entire world, Persia or Rome, as long as it does so for nine months. ${ }^{35} \mathrm{I}$ am not sure that this was Rav's original intention, if it was indeed he who pronounced this teaching in the first place, but it was probably the intention of the redactors of the entire passage of Yoma, somewhere between the sixth and the eighth centuries. The redactors considered that both statements (Rome will vanquish Persia; Persia will vanquish Rome) are worth conserving, even though they contradict each other.

We see therefore that by the time of the redaction of the Babylonian Talmud, Palestinian as well as Babylonian traditions about Rome and Persia were disconnected from their historical and emotional background and were read mainly in a scholastic way. This statement is true especially with regard to Rome, which was geographically and historically distant. From a real empire it became a discursive one. Our analysis allows us therefore to articulate a process of "scholasticization" that characterizes rabbinic discourse in general and its use of the image of Rome in particular. The main steps of this process are listed here:

1. During and after the Bar Kokhba revolt, the hope that Rome would be conquered by Persia (its most important imperial enemy at the time) was expressed and sustained by a simple syllogism. It was the product of a "natural" reaction to Rome as it was perceived and experienced by some Palestinian rabbis. It was derived from the Zeitgeist and was straightaway understandable, and therefore there was no need to corroborate the argument with a scriptural text proof.

2. At the beginning of the third century, during a period of relative calm and prosperity for the Jews in Palestine, the aforementioned tradition went through the exegetical filter of Rabbi. From the fruit of a living experience, the hope expressed in the original teaching of Yehuda ben Ilay became a product of interpreted Scripture, a scholastic object that could be debated without referring to the reality it originally represented.

35. The Vilna version is "the wicked kingdom of Rome" but in all the manuscripts we read "the wicked kingdom" without specification. 
3. This process continued in Babylonia, with Rabbah ben Ulla, whose approach was purely hermeneutical - indeed, he raised the possibility that Rome would be vanquished by Greece, an empire that no longer existed! However, this attitude was not accepted by all rabbis, since some of them apparently still felt engaged with the actual situation of Palestinian Jews in general and rabbis in particular.

4. Sometime between the sixth and the eighth centuries, when the Bavli's passage took shape, the hermeneutical approach seems to have prevailed. Rome, but also Persia, were considered as two literary objects, two symbolic empires, whose connection to the real empires plays no role in the redaction process.

\section{Elevating Rome to the Stage of the Utmost Adversary}

The previous section pointed out some differences in the attitudes of the two rabbinic centers (the Palestinian and the Babylonian) with regard to Rome. Mainly, we identified in the Babylonian Talmud a process in which the image of Rome is detached from its original context and becomes a discursive element. However, even as such Rome is not completely neutral and cannot be freely manipulated. It keeps some specific characters and functions it is supposed to fulfill. In the present section I would like to show that the role of Rome in Babylonian rabbinic discourse is articulated inside a paradigmatic framework, rather than a historical or an eschatological one. The Bavli's Rome is still considered as the greatest adversary of Judaism, but this rivalry is understood to be structural and to a certain extent eternal. It does not end with an ultimate victory for Israel.

Remember that the redactors of the eschatological aggadah from the beginning of Avodah Zarah discussed above, who refer to Rome as "the most important kingdom," do not explain its importance as a result of its role in a divine historical or eschatological plan. Actually, they do not explain it at all but take it as a fact. Even when Rome is given an eschatological role, as in the passage from Yoma 10a read above, it seems to be a result of its greatness and not the reason for it. Rome's greatness becomes then one of the basic characteristics of the literary image of the Roman Empire in Babylonian rabbinic discourse. It does not need to be explained or justified. 
What I would like to show in the following is that the Bavli uses this given greatness of Rome in order to place it as one of the two main elements in a bipolar system. The other element is, of course, Israel. The greatness of Rome reflects that of Israel. It will be very helpful to read in this context another Babylonian reworking of a Palestinian tradition. We can see in it how the Babylonian redactors downplay the eschatological dimension of a Rome tradition in favor of a more structural, paradigmatic one. I will first give the Palestinian tradition, from the tractate Avodah Zarah of the Palestinian Talmud:

A.R. Levi said: on the day Salomon married into [the family/ dynasty of] Pharaoh Necho the king of Egypt, [the angel] Michael descended and planted a reed in the sea, it gathered sediment ${ }^{36}$ around it and a great forest was created and this is the great city of Rome.

B. On the day Jeroboam set up two golden calves, Remus and Romulus came and constructed two huts ${ }^{37}$ in Rome.

C. On the day Elijah disappeared, a king was crowned in Rome. ${ }^{38}$

The structure of the text is easily discernible. It contains three parts, each one representing a crucial historical stage. The development of the kingdom of Rome is explained as a reaction to events that occurred in Israel. The rhythm of the text - each part is shorter than the previous one - provokes an alarming sensation: each misfortune of Israel is paralleled by an increase of Rome's power. This is particularly salient in part B, whose redactors seem to place great emphasis on this inverse parallelism. They do so by a recurrent use of the number two - two calves, two brothers, two huts - all in all three times, four if we include the fact that it is the second stage of the process depicted by the text. Finally, part C, which connects the disappearance of Elijah to the crowning of the first Roman king, gives to the text an eschatological tone: when Elijah comes back, the crowning of the Roman king (and of Rome itself) will be reversed.

It is important to note the context in which this passage is brought up in the Yerushalmi - an elaboration of Mishnah AZ 1:3 that lists several pagan holidays. Our passage specifically interprets the holiday of Kratesis as the celebration of the day in which Rome began its rule (תפשה בו מלכות). However, when the Babylonian

36. שלעטוט. Jastrow reads here של טיט.

37. Hut is used here to translate צריף, but see below note 44.

38. y. AZ 1.2, 39c. See also Shir Hashirim Rabbah 1. 
Talmud gives its version of this teaching, it does not do so in the context of the discussion on the "national holiday" of Rome, ${ }^{39}$ but in a rather long discussion about impieties practiced by the ancient kings of Israel.

Rav Yehuda says [in the name of] Shmuel: When Salomon married Pharaoh's daughter, Gabriel descended and planted a reed in the sea, and it gathered a reef around it, on which the great city of Rome was built. ${ }^{40}$

In a Baraitha it was taught: On the day Jeroboam brought the two golden calves, one into Bethel and the other into Dan, a hut was built, and this developed into Greek Italy. ${ }^{41}$

The relationship between the Babylonian and the Palestinian traditions is not clear. It is possible that both developed independently from a similar source, or that one is an adaptation of the other. In the latter case I would not exclude the historical priority of the Babylonian version - first, it is attributed to Shmuel, who was active before R. Levi; second, there is a close parallel of this version in some manuscripts of the tannaitic compilation Sifre on Deuteronomy; ${ }^{42}$ and third, when compared to the Yerushalmi, the redaction of the Bavli's parallel seems to be much looser.

The first part that links Salomon's marriage to the "geological" creation of Rome is almost identical to the first part of the Yerushalmi's version. As for the second part, the reference to the two brothers disappears, and instead we find a rather curious mention of the places in which Jeroboam has set the calves - Beth El and Dan. This detail corresponds to the biblical account, but it is not clear why the redactor chose to add it here; the mere mention of the two calves would be enough..$^{43}$ The Bavli's version does not

39. See Alyssa M. Gray, Talmud in Exile: The Influence of Yerushalmi Avodah Zarah on the Formation of Bavli Avodah Zarah, Providence, Brown University Press, 2005, p. 124-125.

40. The first part is found also in most witness of Bavli Sanhedrin 21b.

41. $b$. Shabbat 56b. In a tradition that is conserved in the Babylonian Tractate Megillah, and is attributed to 'Ulla, a Palestinian sage from the end of the third century who traveled a lot between Palestine and Babylonia, it is said that Greek Italy is "a great city of Rome". See below.

42. \$52. See Finkelstein, p. 119.

43. Jeroboam is depicted here as someone whose fault was similar to that of the Greeks and the Romans - both prevented Israel from worshipping God in the Temple of Jerusalem and incited them to worship idols. This explains why Jeroboam's action is considered to be what set in motion the construction of Greek Italy. It does not, however, explain why the redactor mentioned the two cities. 
include the third part about Elijah. This makes an eschatological reading of the text rather difficult.

I would like to propose that the Babylonian redactors considered that Jeroboam's sin had created the geometrical condition that allowed the construction of Rome, or at least that they told this story while trying to develop a spatial imagery instead of a chronological, historical one. In fact, a hut, צריף, can have a large basis and a narrow roof. ${ }^{44}$ The two mentioned cities can be regarded as the Palestinian base of the (Roman) hut: it is the line that stretches between Dan, on the north of Galilee, and Beth El, near Jerusalem. In the Palestinian version, the underlined parallelism between Jeroboam's sin and the foundation of Rome is used in order to designate a causal link between the two events, namely, the idea that Jeroboam's vile deeds had a crucial effect on the process that led to the destruction of the Temple, and in that sense they participated in that process. But in the Bavli, this link operates on a structural rather than a causal, historical level.

The following teaching from the Bavli may shed light on this last point. It consists in an exegesis of Ezekiel 26:2 ("Son of man, because Tyre has said of Jerusalem: Aha, she has broken the doors of the nations, she has turned to me, I am filled, she is ruined"), and more precisely of its last two words, "אמלאה חרבה" ("I am filled, she is ruined"). It appears on two occasions in the Bavli, ${ }^{45}$ both times explaining the two Hebrew words as referring to Israel on the one hand and to Rome on the other - once one is "filled" the other one must be ruined, and vice versa. In any case, they cannot prosper (be "filled") at the same time. ${ }^{46}$ The relationship between Israel and Rome is understood in terms of a zero-sum game. The demise of one entails the flourishing of the other, and vice versa, ad infinitum.

44. In fact, the word can also be read as "tzarif" (with a kamatz under the צ), that is -alum (see dictionary Ben Yehuda, v. 11, p. 5686). It is found in several places in the Bavli. It is possible that the redactors of the Yerushalmi's version played on the semantic link between this meaning and the "sediment" (טיט, according to Jastrow's reading) of the first part.

45. b. Pesahim 42b; $b$. Megillah 6a. There's a difference between the two traditions, as one speaks about the wine and the other about the cities. But in the two cases, the "wine" (Edomite) and the city (Caesarea) are metonyms of Rome, as is clear from the context.

46. It is important to note that this exegesis of "I am filled, she is ruined" is not found in Palestinian sources from the Talmudic period. 
It will be interesting to compare the exegesis of "I am filled, she is ruined" to some Palestinian traditions, like the story of the four sages who traveled to Rome from Sifre Deuteronomy 43. In that story, three of the sages cry when they witness how peaceful Rome is, and compare it to the desolate state of Jerusalem. The fourth sage, R. Aqiba, laughs. When his friends ask him to explain his reaction, he replies: "If this is how [God] has rewarded those who anger him, all the more so [will He reward] those who do his will" ${ }^{47}$ Comparing this story to the Bavli's traditions reveals how the discourse about Rome evolved inside rabbinic discourse, between the Palestinian Sifre and the Babylonian Talmud. In both cases we find a comparison between Rome and Jerusalem. ${ }^{48}$ But the comparison in the Sifre's story is much more "heuristic" than programmatic. The sages who compare the tranquility of Rome to the ruined Jerusalem are reacting to what they see. Even Aqiba's saying is derived from common sense, and the master does not feel the need to support it by Scripture. In fact, Aqiba's statement, which is the conclusion of the passage, is a comforting, eschatological message in which Rome is the sign of Israel's redemption and retribution.

Thus, in spite of the fact that both the Babylonian and the Palestinian rabbinic traditions compare Rome to Jerusalem, the difference between them is remarkable. Only in the Bavli's tradition is the comparison articulated as an unending zero-sum game, which is supported by Scripture. In other words, only the Bavli assigns to the two cities a complementary role on a global level, without placing the redemption of the one or the demise of the other as the culminating point of the process.

The role that the Bavli attributes to Rome has its own history, and the following passage allows us to trace its development inside Babylonian rabbinic circles. The text in question figures in the Babylonian tractate Pesahim as a part of a compilation of stories and exegeses, whose main objective is to prove and reinforce the priority of Babylonia over Palestine ${ }^{49}$ One of the first texts

47. Translation in J. Neusner, Persia and Rome in Classical Judaism, p. 8.

48. It is worthwhile to emphasize this point since this text may be the first testimony of the rabbinic representation of the "couple," Rome and Jerusalem. The Mishnah and the Tosefta, for example, do not compare Rome to Israel or to Jerusalem.

49. b. Pesahim 87b-88a. 
in this compilation, in Aramaic, tells the story of a Roman ${ }^{50}$ who came to the Palestinian rabbinic master, R. Hanina. ${ }^{51}$ The Roman provokes the rabbi by saying: "We are better than you". As a proof he quotes the verse from 1 Kings 11:16 that tells how Yoav, the chief commander of David's army, stayed in Edom for six months in the course of which he killed all the male Edomites. "But we," says the Roman, "have had you among us for several years already, and we have not acted towards you in the same manner". The master asks the Roman whether he would care to be answered by a student, and the one chosen is Rabbi Hoshaya. Now, Hoshaya's answer, as it is recorded in the Vilna edition of the Talmud and many manuscripts, goes as follows: "It is because you do not know what to do [with Israel]: you kill them all - they are not among you, those who are among you, you will be called an amputated kingdom". The Aramaic formulation is somewhat odd, and some other versions are clearer. Thus, in three manuscripts - Munich 6, JTS, and Columbia ${ }^{52}$ - the answer goes as follows: "It is because you do not know what you will do: you kill them all - you will not rule over them! You kill those over whom you rule - you will be called an amputated kingdom". ${ }^{53}$ In all the versions the Roman admits that this is exactly the problem of the Romans vis-à-vis the Jews and perhaps in general: "By the wing of Rome, with this we come down and with this we get up".

The picture emerging from the answer given to the Roman is that of a world divided in two - one part is ruled by Rome and the other is not. Jews live in both parts. The Romans could kill or drive out all the Jews from their Empire, but then they would be an "amputated kingdom". What Hoshayah says in fact is that without Israel, Rome will be crippled. This is a very daring statement - the master never wants to acknowledge his dependency on the slave. It shows the rabbinic (Babylonian) conception of the relationship between Rome and the Jews - the latter are a necessary component of the

50. The text speaks about $\min$ (heretic) but from the context it is clear that the person is Roman.

51. According to two mss (Munich 6, JTS, Columbia) it was Rabbi Yehuda the Prince.

52. The same manuscripts that read Rabbi Yehuda instead of Rabbi Hanina.

53. The shorter version (of Vilna and the other manuscripts) is actually more elegant once understood, but this elegancy comes with a cost. 
former; they contribute to its wholeness. This story resonates with another tradition from the Babylonian Talmud in which this idea is articulated even more explicitly. In tractate Avodah Zarah 10b, we are told the story of a Roman official with the highly symbolic name - קטיעה בר שלום (amputation son of peace). When the emperor proposes to eradicate the people of Israel, this official objects by raising two arguments: First, he asks why a verse in Zechariah (2:10) promises to spread Israel "as the four winds of heaven" and not "to the four winds". His answer: "Just as the world cannot exist without four winds, it cannot exist without Israel". Once again, Israel is depicted as an essential component of the world, and of the Roman Empire in particular. The second objection is the same statement found in the Pesahim text - "you will be called an amputated kingdom". ${ }^{54}$ The absence of Israel will have a visible and physical effect on Rome, which will be regarded as crippled. These two stories describe thus a world system in which Rome and Israel are mutual players, each one being dependent on the other. ${ }^{55}$

\section{Equal Brothers}

In spite of the fact that the picture of Rome and Israel as mutually dependent does not appear in Palestinian sources, its roots can be traced back to an early Palestinian tradition that compares Rome to the biblical figure of Edom/Esau, and thus assumes a brotherhood between the two nations. In fact, the date of the emergence of

54. Here most manuscripts read קטיעה instead of קטיעתא in the Pesahim story. See also Ketubot $10 b$ and Nidah $64 b$ for the Hebrew expression דור קטוע (amputated generation).

55. If we were to place the two traditions, from Pesahim and from AZ, on a chronological line, it is possible that the AZ story is a later tradition than the Pesahim one. This is suggested by the fact that the AZ text seems to quote the saying from Pesahim - you will be called an amputated kingdom - as it is. It does not change it to the first person plural even though it is attributed to a Roman. If this tradition is indeed later, it might indicate a development in Babylonian rabbinic attitude towards Rome that becomes bolder with time: in the AZ text, it is a Roman and not a Jew who admits that Rome is dependent on Israel; according to the later Bavli's text, the Romans themselves accept this bold rabbinic conception. This development can be easily explained. As time passed, the historical reality in which the Palestinian rabbinic traditions about Rome were produced grew more distant. Thus, the idea of the two entities, Israel and Rome, as mutually dependent could be expressed much more bluntly. 
this idea is still under debate among scholars. Thus, Neusner claims that it is only after the Christianization of the Empire that rabbinic sources took the two nations in Rebecca's womb, Jacob and Esau, to be Israel and Rome. ${ }^{56}$ But other scholars claim that the equation Esau-Rome was made well before the fourth century. In that respect, it is interesting to note that even Israel Yuval, one of the most important advocates of the "rabbinic Judaism is born out of Christianity" thesis, claims that the identification of Esau with Rome dates to the first half of the second century CE. According to Yuval, Rabbi Aqiva was probably the first one to make the analogy between Edom and Rome when he interpreted Numbers 24:17 (דרך כוכב מיעקב) as a prophecy about Bar Kokhba and the following verse, about Edom, as a metaphor for the city of Rome.${ }^{57}$ Be that as it may, it is very probable that for the redactors of the Bavli this identification was a ready-made convention received from Palestine.

Whereas some work has been done on the history of the identification of Rome with Esau, very little attention has been paid to the reasons for this rather peculiar and in any case not obvious discursive tactic. I think that the best way to understand the emergence of the Israel-Rome brotherhood idea is to regard it as a myth. If Yuval and others are right, this myth emerges in the second century CE, during or after the Bar Kokhba revolt - in other words, in an extremely tense moment in the history of the

56. J. Neusner, Persia and Rome in Classical Judaism, p. 17-73. See also his Judaism in the Matrix of Christianity, Philadelphia, Fortress, 1996, p. 76, cited in Schremer, Brothers, p. 227, n. 61. Unfortunately, Neusner's argument in support of his claim is not thorougly developed, but one cannot ignore that even if the identification of Edom with Rome is from the second century, it is only in the compilations from the fifth century onwards that its presence is by no means contestable. Of course, that can be easily explained by the fact that we do not have an exegetical compilation dedicated to the book of Genesis, where the story of Esau and Jacob is told. It is only in the fifth century that such a compilation is redacted -Genesis Rabbah (in Palestine), and indeed, in it we find the greatest number of traditions linking Rome to Esau/Edom. It is possible that at least some of the traditions recorded in Genesis Rabbah precede the date of redaction of the compilation.

57. y. Ta'anit 4.8, 68d; I. Yuval, Two nations, p. 25. Already Louis Ginzberg has claimed that the designation of Rome by the biblical names Esau and Edom is very old (id., The Legends of the Jews, Philadelphia, Jewish Publication Society, 1968, vol. 5, p. 272, n. 19) even though he argues that the "appellation of Edom for Rome is rarely found in tannaitic sources" (quoted in A. Schremer, ibid). See also M. Hadas-Lebel, Jérusalem contre Rome, 463. 
Israel-Rome relationship. A myth, and a powerful one, was needed in order to contain the explosive range of contradictory emotions, interests, experiences, and motivations that life under Roman rule in Palestine involved. No simple idea or rational theory would work. Thus, the Jacob and Esau story was chosen for various reasons to be the infrastructure of a myth that would serve the rabbis from then on to talk about and to reflect upon their relationship with Rome. $^{58}$

The myth arrived in Babylonia during the third or the fourth century, but the political and social context that engendered and sustained it stayed in Palestine. Obviously, the domination of Rome over Palestinian Jews was felt less in Babylonia than in Palestine, and the relationship between the two brothers/nations is therefore described as a relationship between two equals at least on some level. In any case, it is difficult to find in the Bavli the bitter attitude of some Palestinian sources that criticize the hypocrisy of Rome. We will not find in the Talmud of Babylonia a statement like that of Sifre Deuteronomy on Deut 32:27: "when Israel is in distress the Nations of the world distance themselves from them and act as if they never knew them... but when Israel prospers the Nations of the world flatter them and act as if they were brothers". As was shown by Adiel Schremer, the nation in question is none other than Rome. ${ }^{59}$ Another, probably later, example of this Palestinian rabbinic bitterness towards Rome is found in Genesis Rabbah 37, in an exegesis on Genesis 10:4 - "And the sons of Yavan were Alisha and Tarshis, Kitim and Dodanim". The same genealogical list appears in 1 Chronicles 1:11, but instead of Dodanim, a word that means "cousins," the text reads Rodanim - "tyrants". The exegete, R. Hanan, explains this difference as follows: "When Israel goes up, they come and say to them - we are your cousins. But when Israel goes down, they come and tyrannize it". That "they" refers to the Romans is clear from the context. ${ }^{60}$ This bitter irony does

58. See the discussion in Katell Berthelot's article in this volume.

59. Schremer, Brothers Estranged, p. 134.

60. The name before Dodanim/Rodanim in both Genesis and Chronicles is Kittim, interpreted as "Italia" in the previous sentence of the exegesis, and in general a known nickname of the Romans already in the texts of Qumran. It seems in fact that the exegete reads the last word of the verse (Dodanim/Rodanim) not as the name of another nation but rather as an adjective of Kittim. 
not find its way to the Babylonian sources. The brotherhood of the two nations is taken for granted and is used only rarely in order to express negative feelings towards Rome. ${ }^{61}$ It is used instead to compare the two, in a more or less explicit way.

We have already seen that the Babylonian redactors conceived of Israel as a crucial component of the Empire, essential to its existence. The following Babylonian exegesis on Genesis 25:23 ("And God said to her: two nations are in your womb...") provides a picture of two equal brothers with the power of one reflected by the other:

"And God said to her: Two nations are in your womb" (Gen 25:23). Do not read "nations" (גוים) but rather "lords" (גיים/גאים). And Rav Yehuda said in the name of Rav - these are Antoninus and Rabbi, whose table never lacked radish, lettuce or cucumber, either in summer or winter!

This "couple" - Rabbi and Antoninus - figures into many rabbinic sources, from Palestine as well as from Babylonia. In the Bavli, the couple is charged with a symbolic load that makes the two characters the representatives of their respective groups. The teaching here describes them as equals, at least on an economic level - the Jewish leader is as rich as the Roman one. This is a rare example of a materialistic understanding of the equality principle. The rabbis know of course that the greatness of Rome cannot be compared to that of Jewish cities in Palestine. An interesting and subtle example of this awareness is in the sugiya from the Babylonian Tractate Megila. It is a saying attributed to the Palestinian sage 'Ulla'

Greek's Italy is the great city of Rome, which covers an area of three hundred parsangs by three hundred. It has three hundred sixtyfive markets, corresponding to the number of days of the sun [year]. And the smallest among them is that of the poultry sellers, which is sixteen mil by sixteen. The king dines every day in one of them. Everyone who resides in the city, even if he was not born there, takes a reward from the king's house. And everyone who was born there, even

61. One source is worth mentioning - in $b$. Pesahim $118 \mathrm{~b}$, Rome itself uses the argument of its brotherhood with Israel in order to convince God to let it give a present to the Messiah.

62. Most manuscripts read גאים, but the exegesis is on the word "nations" in the biblical text (גוים), written without the 1 in the Masoretic text.

63. See note 22 . 
though he does not reside there, takes a reward from the king's house. ${ }^{64}$ There are three thousand baths in it, and five hundred windows ${ }^{65}$ from which arises smoke outside the wall. One side of it is [bounded] by the sea, one side by hills and mountains, one side by a barrier of iron, and one side by pebbly ground and swamp. ${ }^{66}$

The historical kernel beyond this description is less important for our discussion here. The most stunning characteristic of this passage is its lack of negative attitude, either in its content, or in the context in which it is brought into the Talmudic discussion. In fact, we can even speak of pure admiration. The city of Rome is praised not only on geographical grounds, but also on political ones. Its king participates in the active life of the city - each day he eats in a different market. Its residents get economic benefits from the city treasure, even though they were not born there. It is well protected but also well designed - the smoke of the fire used to heat the water is evacuated outside the city.

To go back to the question of the comparison between Israel and Rome, it is interesting to note that this admiring account arrives several passages after a description of some Palestinian Jewish cities that bear some resemblance to the description of Rome. Thus, Tiberias is mentioned as a city that is bounded by the sea. The size of the "trail of milk and honey" around the city of Sepphoris according to Reish Lakish is "sixteen mil by sixteen mil," the same as the size of the smallest market in Rome. These parallels cannot lead us to any firm conclusion, but it seems that, at least for the redactors of the text, special care was taken to harmonize the different traditions in the sugiya, whether they concerned Rome or Jewish cities. Their objective, so it seems, was to develop and substantiate a language that would allow them to speak about Rome and Israel using the same set of signifiers.

The redactors are taking a further step, much more explicit, in their effort to develop a common language to speak about Rome and Israel when they bring two exegeses on Zech. 9:7 ("And I will take away his blood out of his mouth and his detestable things from between his teeth, and he also shall be remnant for our God, and he

64. Some manuscripts mention only one category (those who reside but were not born there, or those who were born but do not reside here).

65. Some manuscripts - "in which one of them".

66. $b$. Megillah $6 \mathrm{~b}$. 
shall be as a chief in Judah, and Ekron as a Jebusite"). The names of Palestinian cities or regions - Judah, Ekron - are understood by the exegete as "theaters and circuses in Edom in which one day the chief of Judah will publicly teach the Torah" ${ }^{67}$ Once again we find here what might have been a Palestinian rabbinic tradition, in which prophetic discourse about the salvation of Israel was read as an apocalyptic account of the victory of the Jews over Rome. But in the context of the discussion in the Bavli it is mainly used to emphasize the possibility of speaking about Rome in biblical and Jewish terms. What is at stake is less the redemption of Israel at the end of times, but rather the description of the two entities - Rome as a mirror image of Israel. Indeed, the first part of this Talmudic discussion ends with the midrash cited above, according to which Rome and Israel cannot prosper at the same time - when one succeeds the other is devastated.$^{68}$ From the way this exegesis is articulated, it is clear that we are not dealing here with a linear historical process, but rather with a circular one - one is up, the other is down, and so forth. That is why talking about one is, essentially, talking about the other.

\section{Conclusion}

As I mentioned earlier, the rabbinic movement in Palestine presented Rome as its main adversary not only because it was true, but also due to the rhetorical benefits that such a claim must have brought. Presenting the rabbis as the adversaries of the Romans contributed to the symbolic status of the rabbis and of rabbinic Judaism. It is against this background that we should understand the use of rabbinic traditions about Rome in Palestine. The rabbis of the Bavli imported the Palestinian idea according to which Rome is the fiercest enemy of (rabbinic) Judaism, and like them used it in order to promote their Jewish and rabbinic values. Richard Kalmin

67. b. Megillah 6a.

68. It is possible that the manuscript variants retain traces of the evolution from a linear conception of the relationship between Rome and Israel to a circular one. Some manuscripts (Göttingen, Munich 95, Vatican 134) read only "If one is filled the other is ruined" in what may express a linear conception. But other manuscripts (London, Munich 140, NY Columbia, Oxford) raise the possibility that the link between prosperity and ruin is bidirectional. 
made a very convincing case for this thesis when he showed that in the Bavli's accounts of Roman persecutions, one of the most important prohibitions issued by the Romans concerned Torah study. However, in the Palestinian accounts of the same or other persecutions, no such prohibition appears. ${ }^{69}$ Evidently, Torah study was a very important practice and of value in rabbinic circles in Palestine as well, but it seems that only in Babylonia it became distinctive for rabbis, an identity mark of the rabbinic movement and the type of Jewishness they articulated. In other words, rabbis in Sasanian Babylonia used a historically charged image of Rome in order to promote what they considered to be a genuine and crucial element of Jewish existence. They acknowledged the symbolic value of Rome conferred upon it in Palestinian sources, and at the same time they enhanced and transformed it to promote their own version of rabbinic Judaism.

The purpose of this article was to expose the infrastructure that allowed the Babylonian rabbis to use Rome in such a way. We have seen not only that Babylonian rabbis inherited the Palestinian image of Rome, but that along with this image they inherited its discursive role as a fierce adversary against whom rabbinic Judaism defined itself. I hope to have shown that Rome of the Babylonian Talmud is an entity that is both concrete and abstract. It is concrete in the sense that its Palestinian origin is recognized by the rabbis and utilized by them for its high symbolic value. It is abstract because most of the time when the Babylonian rabbis speak about Rome they do not refer to an actual kingdom, but rather to an image that they find in the sources and to which they attribute a discursive role. There is therefore a certain duality inside the Babylonian Rome. On the one hand it is used as an empty mirror, drawn in order to construct the identity of Israel. On the other hand, since it is a literary object whose origin is in Palestine, it must be consistent with other Palestinian elements known to the rabbis. Even though it is a literary object, the Babylonian rabbis still wish to present it as a real one.

The reason for which the Babylonian rabbis wished to define Rome as a real rather than mythical enemy is precisely because they were using Rome as a tool by which they could construct the

69. R. Kalmin, Jewish Babylonia, p. 19-36. 
identity of Israel. Just as Israel is an entity that is both abstract and real, so must its twin sister, Rome, be as well. Thus, the duality between the realistic and abstract dimensions of the Bavli's image of Rome is a reflection of the same duality in its image of Israel. This is cleverly demonstrated by the following story, from the Babylonian tracate Avodah Zarah:

Onkelos the son of Kalonymus became a proselyte. ${ }^{70}$

The Emperor sent a contingent ${ }^{71}$ after him.

He [Onkelos] enticed them by [citing] scriptural verses.

They became proselytes.

The Emperor sent another contingent after him. He told them: do not say anything to him!

When they held him and left, he said to them: Let me tell you just an ordinary thing: the torchlighter carries the light in front of the afifior, the afifior in front of the leader [dukas], the leader in front of the governor [hegmona], the governor in front of the chief officer; but does the chief officer carry the light in front of the people?

They replied: No.

He said: The Holy One, blessed be He, carries the light before Israel, as it is written: "And the Lord went before them [...in a pillar of fire to give them light] (Ex 13:21).

They became proselytes.

Again [the Emperor] sent another contingent. He said to them: do not converse with him!

When they took hold of him and went away, he saw the mezuzah $h^{72}$ and he placed his hand on it.

He said to them: What is this?

They replied: You tell us then.

He said: According to universal custom, the mortal king dwells within, and his servants keep guard on him from without; but [in the case of] the Holy One, blessed be He, it is His servants who dwell within while He keeps guard on them from without. As it is said: The "Lord shall guard thy going out and thy coming in from this time forth and for evermore" (Ps 121:8).

They became proselytes.

He sent for him no more.

70. An account of his conversion is found in $b$. Gittin 56b, in which he is described as the son of Titus' sister.

71. Vilna, the Pesaro Print and a fragment (Cambridge - Westminster College G.F. Talmudica II 266-269) add "of Romans" as a specification to the first two "contingents". Ms. JTS does it only for the first one. Mss Munich 95, Paris 1337 do not mention it at all.

72. Ms. Paris: "which was fixed on the door-frame". 
What strikes me the most in this story is that it lacks any indication of place. We do not know where Onkelos resides, where the contingents come from, where the Emperor waits in vain for them to return. The text does not mention even one place or architectural entity (room, store, courtyard, etc.). Only the mezuzah, a small inexpensive object, is mentioned. Rome, where the emperor is, and Israel, were Onkelos is supposed to be, are depicted as two abstract entities that are separated by the mezuzah, an object that symbolizes God's protection. ${ }^{73}$

Israel, as it is presented here, is an "empire" bounded and protected by no other king than God. His protection, of course, cannot be compared to the one offered by an emperor in flesh and blood. Everyone can enter "Israel," as this story so clearly shows, when it describes the conversion of the Emperor's envoys in only one word. It is a spiritual assembly, an abstract ecclesia.

The geographical and architectural emptiness of the story gives the impression that only the two entities - Rome and Israel - exist in the world: one can choose to join either the kingdom that is led by the mortal king, or the one that is protected by God. This conclusion is perhaps the target of the jeu de miroir between Rome and Israel that I have tried to examine in this article. In other words, Rome became a crucial element in the discourse of Babylonian rabbinic circles precisely because it contributed to articulating their identity. That is why it was important for the redactors of the Bavli to always leave ambiguous the possibility of Rome's total triumph or total demise. A careful system that prevents Rome from spreading all over the world is necessary, since without it, Rome would be everywhere. It would no longer be an Other.

ron.naiweld@ehess.fr

73. In the Palestinian Talmud ( $y$. Peah 1:1) there is a story about Rav in which he gave a mezuzah as a present to a Persian king. The latter was offended by how cheap the present was. Rav explained to him that in reality it was the best present that he could get, since contrary to a precious stone that must be protected by the one who owns it, the mezuzah protects its owner even while he is asleep. 